Acta vet. scand. $1964,5,384-393$.

From the Medical Department for Non-Ruminants, Royal Veterinary College, Stockhom, and the Department of Anatomy, University of Gothenburg, Sweden.

\title{
CAPILLARY FORM AND FUNCTION IN DOGS WITH EXPERIMENTAL HEPATITIS CONTAGIOSA CANIS
}

AN INTRAVITAL MICROVASCULAR STUDY*)

By

Gert Lindblad, P-I. Brånemark and J. Lindström

The purpose of this study was to throw light on the microcirculatory disturbances which are presumed to occur in Hepatitis contagiosa canis (H.c.c.), as histological changes in the endothelial cells and disturbances in tissue nutrition are common phenomena (Rubarth 1947). The investigation was further prompted by the observations of a regularly occurring tendency to bleed (Smith 1951, Hodgman \& Larin 1953, Poppensiek 1952) and peripheral blood disorders in the form of granulocytopenia (Lindblad \& Persson 1962) and thrombocytopenia (Lindblad \& Bäckgren 1964).

\section{MATERIAL}

Six puppies lacking antibodies (Espmarck \& Salenstedt 1961) of a mixed breed, whose ages ranged from 2 to 4 months, were used in the experiment. One of them served as a non-inoculated control, and another one was used for continuous observation of the progress of the disease by a chamber technique. As references

*) Supported by grants from National Institutes of Health (H-5724), United States Public Health Service, the Swedish Association against Heart and Chest Diseases, and "Anslag för främjande av medicinsk forskning vid Veterinärhögskolan". 
for control we also used observations on older dogs whose mesenteries were studied under normal conditions. The virus material used was an SBL strain (titre: $7.5 \mathrm{TCID}_{50} / \mathrm{ml}$ ) ${ }^{\star}$ ).

\section{METHODS}

In the 4 animals, which were observed on one occasion each, $4 \mathrm{ml}$ of undiluted virus suspension were inoculated intraperitoneally, and in the ear-chamber case $7 \mathrm{ml}$ were injected. The development of disease was followed by temperature readings and transaminase determinations (Lindblad \& Persson 1962). The structure and the function of the capillary bed were studied by direct microscopy of the vital tissue in situ. The observations were made in a Leitz intravital microscope; conjunctival vessels were studied in oblique light through. an Ultropak illuminator, objective $\mathrm{UO} \times 3.8$ and $\times 6.5$ respectively, cinematographic recording on $16 \mathrm{~mm}$ colour film Kodak chrome II; mesenteric vessels were exposed by pulling out a suitable section of the gut with the mesentery through an incision in the linea alba and studied in transillumination with a modified Berek condenser, objective plane $\times 4$ and $U O \times 75$ and $\times 100$, recording both on $16 \mathrm{~mm}$ colour film and by single exposures on black and white film, Gevaert 39C56 Scientia, with short-flash exposure (1/10:000 seconds). Fluidbalance and a local temperature corresponding to the body-temperature were maintained with Tyrode's solution. During the observations the animals were anaesthetized with fractionated Nembutal ${ }^{\circledR}$ and respiration was checked with an endotracheal tube.

Although the method described is sufficient for analysis of microcirculatory conditions at the stage of the disease at which the mesentery is exposed, it was considered that it would be a great advantage to be able to observe and follow the whole sequence of events, from inoculation to the final stage, in one animal without using anaesthesia and surgery.

To that end, an ear chamber was installed in one animal, permitting continuous studies of connective-tissue capillaries. The chamber used has been described elsewhere (Brånemark \& Lindström 1963). It is based on the following principle: A thin layer of perichondrial connective tissue in the ear is enclosed between a cover slip and a glass slide in a titanium frame-work, with a tissue-layer thickness of approximately $200 \mu$. This tissue thus represents the preformed tissue, in the centre of which a small defect is produced, with a diameter of about $10,000 \mu$. Here a space of approximately $40 \mu$ in depth is produced, and within 2 weeks the space is invaded by granulation tissue and vessels. This arrangement permits observation of two types of tissues, preformed connective tissue and granulation tissue. Microscopical studies on the non-anaesthetized dog were made with the same equipment as that used for the mesentery.

*) Obtained from R. Salenstedt, V.M.D., National Bacteriological Laboratory, Stockholm. 


\section{RESULTS}

The clinical picture was fairly uniform in all the dogs as regards the loss of appetite, drowsiness, and apathy. In the earchamber case a severe type of the disease developed and the

Table 1. Transaminase levels and temperatures from dogs with experimental H.c.c.

\begin{tabular}{|c|c|c|c|c|}
\hline $\begin{array}{l}\text { Day after } \\
\text { inoculation }\end{array}$ & Dog no. & $\begin{array}{l}\text { G.O.T. }+++ \\
\text { units }\end{array}$ & $\begin{array}{l}\text { O.T.C. }+++ \\
\text { units }\end{array}$ & $\underset{{ }^{\circ} \mathbf{C}}{\text { Temperature }}$ \\
\hline \multirow[t]{5}{*}{0} & 1 & 30.5 & - & 38.2 \\
\hline & 2 & $-^{+}$ & - & 38.6 \\
\hline & 3 & 26 & - & 38.4 \\
\hline & (4) & 40 & - & 38.6 \\
\hline & 5 & 30 & - & 38.0 \\
\hline-1 & $6^{*}$ & $94.5^{++}$ & - & 38.4 \\
\hline \multirow[t]{6}{*}{2} & 1 & - & - & 40.0 \\
\hline & 2 & - & - & 38.8 \\
\hline & 3 & - & - & 39.6 \\
\hline & (4) & - & - & 38.5 \\
\hline & 5 & 42.5 & 21.6 & 39.7 \\
\hline & $6^{*}$ & 64 & - & 40.0 \\
\hline \multirow[t]{6}{*}{3} & 1 & - & - & 40.9 \\
\hline & 2 & 59.5 & 7.0 & 39.7 \\
\hline & 3 & 33 & 0.7 & 40.9 \\
\hline & (4) & - & - & 38.6 \\
\hline & 5 & 42.5 & 21.6 & 40.7 \\
\hline & $6^{\star}$ & - & - & 40.7 \\
\hline \multirow[t]{6}{*}{4} & $1^{*}$ & 68.0 & 8.1 & 39.6 \\
\hline & $2^{\star}$ & 145 & 43 & 39.1 \\
\hline & 3 & - & - & 39.2 \\
\hline & (4) & - & - & 38.8 \\
\hline & $5^{\star}$ & 138 & 41.6 & 39.5 \\
\hline & $6^{*}$ & - & - & 40.0 \\
\hline \multirow[t]{3}{*}{5} & $3^{\star}$ & 37 & 4.5 & 40.0 \\
\hline & $(4)^{*}$ & 42 & 0 & 38.2 \\
\hline & $6^{*}$ & 205 & - & 40.5 \\
\hline 6 & $6^{*}$ & 1175 & - & 38.6 \\
\hline 7 & $6^{*}$ & - & - & 36.6 \\
\hline
\end{tabular}

(4) $=$ control $6=$ the dog with an installed ear-chamber

* = intravital microscopical observations made on the same day

$+=$ lost by accident

$++=$ this high value was unaccountable

$+++=$ normal values given by Lindblad \& Persson (1962): G.O.T. Mean value $17.8 \pm$ s. d. 6.2 number of dogs 166 O.C.T. $\quad, \quad, \quad 2.2 \pm$ s. d. $1.6 \quad " \quad$ " $\quad 159$ 
animal died 7 days after inoculation. The results of the temperature readings and transaminase determinations are shown in table 1 .

The conjunctivas.

Normal animals: The capillary bed showed normal structure and normal flow.

Inoculated animals: The capillary bed was dominated by markedly dilated venules with slowed-down flow, particularly noticeable at the limbus corneae, which was possibly somewhat diffusely defined and oedematous. In some capillaries there was plasma skimming as a typical phenomenon. A particularly noteworthy fact is that complete cessation of flow was not seen in any animal in any part of the conjunctival vascular bed studied, either in arterioles, capillaries, or venules.

The mesentery.

Normal animals: After local mechanical trauma by stretching, the mesentery showed a few well-defined, localized, small peripheral or perivenular haemorrhages which did not tend to progress. The venules were clothed with a dense mass of granulocytes. The flow in the arterioles was virtually normal with respect to rate and type, and the flow in the venules was slowed down but only moderately so, the rate being $0.5 \mathrm{~mm}$ per second. There was no increased tendency to adhesion between the granulocytes attached to the wall and the passing blood-cells, red, white, and thrombocytes.

Inoculated animals: Macroscopically, the mesentery showed diffuse small haemorrhages after only minimal mechanical trauma by stretching. Microscopically, in the early stages the arterioles were virtually normal with respect to structure and flow, whereas capillaries and venules were the seats of characteristic changes. The venules were dilated and, notably in the final phase, the flow was slowed down to a rate of about $0.05-0.1 \mathrm{~mm}$ per second. At this time even the arterioles were dilated and their corpuscular flow velocity was reduced. In some vessels there was complete cessation of flow temporarily. In these vessels, the red blood-cells were seen lying in clumps with difficultly discernible borders between the individual cells, but, characteristically, they still seemed to retain their corpuscular integrity, 


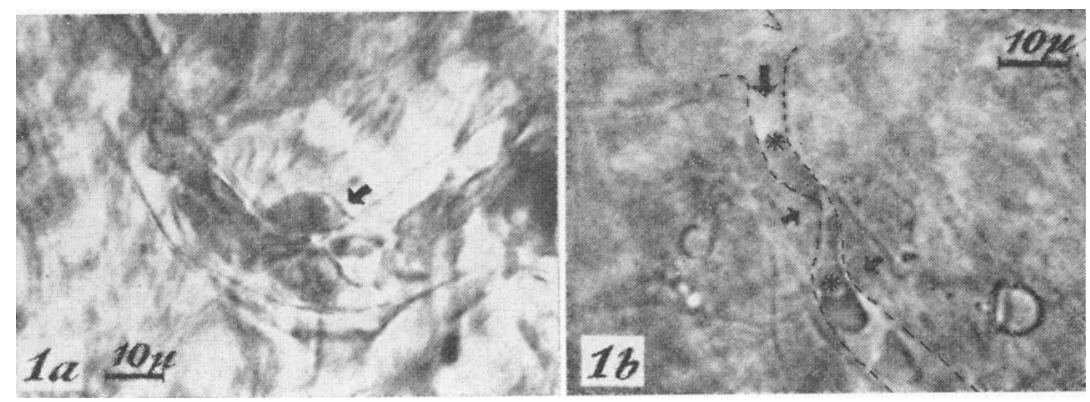

Fig. 1 a. Nuclear region of an endothelial cell (indicated by the arrow) with swelling and probably erythrocytes contained in the adjacent cytoplasm (mesentery). Enlargement from $35 \mathrm{~mm}$ Gevaert 39 C 56 Scientia.

F i g. 1 b. Capillary flow impaired by endothelial swelling (at arrows) demonstrated by narrow capillary diameter and deformation of passing erythrocytes (at $\mathrm{x}$ ) (ear-chamber). Enlargement from $16 \mathrm{~mm}$ colour film.

so that when the blood-cell mass began to move again they were separated from it as individual corpuscular elements without any observable tendency to intercorpuscular adhesion. These red cells showed the same degree of plasticity and deformability as individual blood-cells and could therefore pass through narrow capillary parts, which was seen when, via capillaries, they were slowly poured into collecting venules. Another characteristic feature was that in capillaries and venules with a slow flow-rate (less than $0.1 \mathrm{~mm}$ per second) the red blood-cells were also seen to occur quite free and mobile in relation to each other. In the final stage crenated red cells occurred. Observations in the chamber case disclosed that these erythrocytes possessed a high degree of plasticity, and thus did not stick in the narrow capillary passages.

The capillary wall: The endothelial cells showed no definite pathological changes, except for a varying degree of swelling in some cells from suggested to marked (fig. 1 a), usually localized to the nuclear region. Accordingly, the capillary lumen was reduced, with accompanying impairment of corpuscular flow (see fig. $1 \mathrm{~b}$ ).

In the periendothelial granulated cells the granules were situated peripherally and coarse. Disruption of these cells was not seen, but in one case probable granules were seen inside the capillary lumen. 


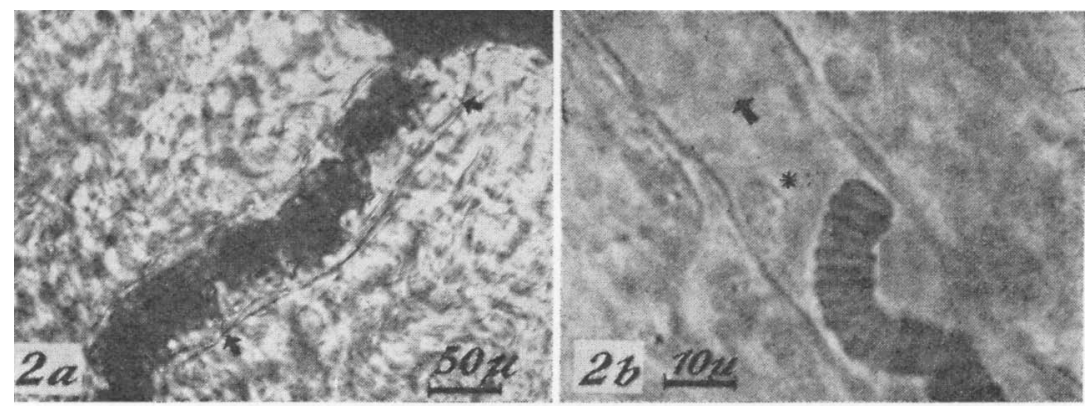

F i g. 2 a. Non-granulated monocytic cells (lymphocytes ?) attached to the wall, about $6-8 \mu$ in diameter, in a venule (mesentery). Enlargement from $35 \mathrm{~mm}$ Gevaert 39 C 56 Scientia.

F i g. 2 b. Small "monocyte" adhering to the wall (at $x$ ) in a venule with almost stagnated flow, containing erythrocytes in typical rouleaux

formation (ear chamber). Enlargement from $16 \mathrm{~mm}$ colour film.

The thrombocytes were remarkably few in number. They showed no tendency to adhere to each other or to the endothelial wall, and "blood-plate thrombi" were not seen. However, in the final stage of the ear-chamber case, a few amorphous thrombi were seen in venules of $50-75 \mu$. The masses adhering to the wall were covered with erythrocytes, but no platelets or granulocytes were observed.

The granulocytes were characteristically few. Only sparse granulated white cells were seen in the circulating blood or adherent to the endothelium, in contrast to the observations after local mechanical trauma in normal controls. On the other hand, a moderate number of cells were seen which adhered to the endothelium and which were of smaller diameter, about $6-8 \mu$, non-granulated, and possibly of the monocyte series; they also occurred as a form with still smaller diameter and could have been lymphocytes (figs. $2 \mathrm{a}$ and $b$ ).

Diapedesis: Very quickly, even with extremely gentle handling of the intestine and mesentery, there occurred numerous rapidly progressing perivenular, possible also pericapillary, diffuse haemorrhages with escape of erythrocytes which continued until the mesenteric tissue was imbued with red blood-cells (figs. 3,4 , and 5). The same phenomenon was seen in the omentum. Gross examination and low-power microscopical observation of the organs in the abdomen and liver revealed that the changes were predominantly located in the liver, with swelling and 


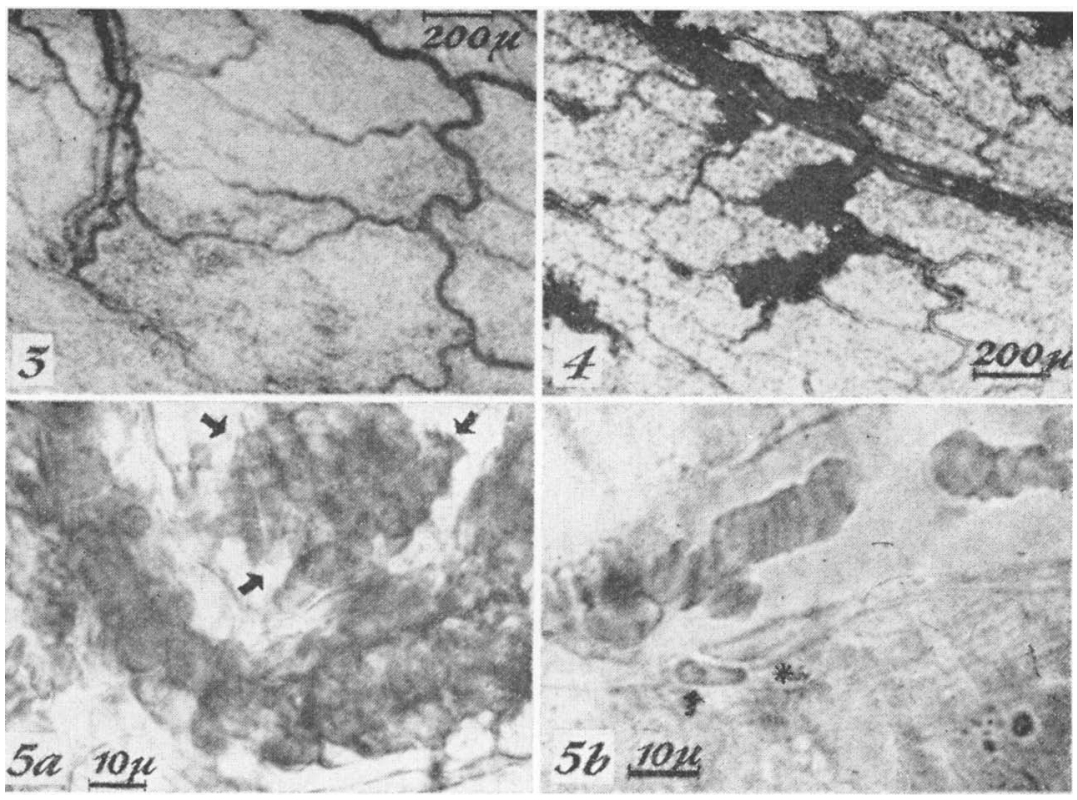

Fig s. 3 and 4. Diffuse and circumscribed escape of erythrocytes, illustrating different degrees of endothelial damage (mesentery). Enlargement from $35 \mathrm{~mm}$ Gevaert 39 C 56 Scientia.

F ig. 5 a. Typical perivenular escape of erythrocytes marked by arrows (mesentery). Enlargement from $35 \mathrm{~mm}$ Gevaert 39 C 56 Scientia.

$\mathrm{F}$ i g. $5 \mathrm{~b}$. A single erythrocyte close to the endothelial nucleus (x) after passage through the venular endothelium (ear-chamber). Enlargement from $16 \mathrm{~mm}$ colour film.

vascular stasis. Oedema of the thymus and fibrin precipitations intraperitoneally occurred in varying degrees. The lymph nodes at the root of the mesentery related to the drainage of the jejunum and ileum were characteristically enlarged, of a brownish red colour, and in the cut section bulgingly oedematous.

Characteristic petechiae in the skin and mucous membranes were observed in the ear-chamber case.

\section{ĊONCLUSION}

The intravital microscopical observations of capillary form and function in H.c.c. show that characteristic changes occur which predominantly involve the venules. The flow in the venules is characteristically slowed down, which results in a high 
arteriolo-venular flow ratio in comparison with, for instance, the findings after mechanical trauma. The endothelial wall is not coated with granulocytes but with relatively few cells of smaller diameter, not identified with certainty but possibly being monocytic cell elements. The thrombocytes are reduced in number, which is well consistent with the observed peripheral granulocytopenia and thrombocytopenia, and show no tendency to adhesion. The venular thrombi observed in the final stages might represent local deposits of fibrin (cf. identified fibrin in liver sinusoids, observed in corresponding stages by electron microscopy, Lindblad \& Björkman 1964). The periendothelial granulated cells show marginal location of coarse granules but no disruption. Numerous diffuse perivenular and sometimes periarteriolar haemorrhages occur, as well as passage of single erythrocytes through the capillary endothelium. In the final stage there appeared crenated red cells in increasing numbers, probably due to fluid-balance disturbances, and the corpuscular flow velocity in the microvessels, as well as in the arterioles, was very much reduced.

The number of examined animals is of course fairly small. But since the essential changes occurred regularly, and the progress of the disease could be studied continuously, the observations seem, in principle, to be sufficient as the basis for a description of the characteristic capillary disturbances in H.c.c.

\section{REFERENCES}

Brånemark, P-I. \& Lindström, J.: A modified rabbit's ear chamber for high-power, high-resolution studies in regenerated and preformed tissues. Anat. Rec. 1963, 145, 533-540.

Espmark, J. A. \& Salenstedt, R.: Haemagglutination-inhibition test for titration of antibodies against Hepatitis contagiosa canis. (Infectious Canine Hepatitis). Arch. ges. Virusforsch. 1961, 11, $64-72$.

Hodgman, S. F. J. \& Larin, N. M.: Diagnosis of canine virus hepatitis (Rubarth's disease). Vet. Rec. 1953, 65, 447-450.

Lindblad, G. \& Björkman, N.: Ultrastructural alterations in sinusoidal endothelium of liver and bone marrow in dogs with experimental Hepatitis contagiosa canis. Acta path. microbiol. scand. In press.

Lindblad, G. \& Bäckgren, A. W.: Megakaryocytes, thrombocytes, and blood-clotting time in dogs with experimental Hepatitis contagiosa canis. Acta vet. scand. 1964, 5, 370-383. 
Lindblad, G. \& Persson, F.: Transaminase and transferase activities in blood plasma of dogs with experimentally produced Hepatitis contagiosa canis (H.c.c.). Acta vet. scand. 1962, 3, 378-390.

Poppensiek, G. C.: Virus diseases of dogs: With special reference to infectious hepatitis. Vet. Med. 1952, 47, 282—284, 287.

Rubarth, S.: An acute virus disease with liver lesions in dogs (Hepatitis contagiosa canis). Acta path. microbiol. scand. (1947) Suppl. 69, 1-222.

Smith, D. L. T.: Observations on infectious canine hepatitis. Am. J. vet. Res. 1951, 12, 38-43.

\section{SUMMARY}

Capillary form and function were studied in dogs with experimentally produced Hepatitis contagiosa canis (H.c.c.). The observations were made in an intravital microscope (Leitz) and comprised conjuntival and mesenteric vessels as well as connective tissue in the ear chamber. The recordings were made on $16 \mathrm{~mm}$ colour film and by single exposures on black and white film. It was found that the flow in the venules was characteristically slowed down with a resulting high arteriolo-venular flow ratio. In the final stages, progressing endothelial swelling occurred impairing corpuscular flow in the capillaries. At the same time, crenated but deformable erythrocytes appeared. In various places cells of small diameter, not identified with certainty, were attached to the endothelial wall. No coating with granulocytes was seen. The thrombocytes were reduced in number and showed no tendency to adhesion. Granular changes were seen in periendothelial granulated cells. Numerous diffuse perivascular haemorrhages occurred.

\section{ZUSAMMENFASSUNG}

Die Struktur und die Funktion der Kapillaren bei Hunden mit experimenteller Hepatitis contagiosa canis.

Eine Vitalmikroskopische Studie.

Die Struktur und die Funktion der Kapillaren wurde studiert an Hunden mit experimentell hervorgerufener H.c.c. Die Beobachtungen wurden mit Hilfe des Vitalmikroskops (Leitz) teils an Bindehaut und Mesenterialgefässen, teils am Bindegewebe der Ohrenkammer durchgeführt. Die Registrierung erfolgte auf $16 \mathrm{~mm}$ Farbfilm und mit Einzelbildregistrierung auf schwarz-weiss Film. Es ist möglich eine charakteristische Verlangsamung der Durchströmung in den Venulae mit einem hohen arteriovenularen Durchströmungsverhältnis festzustellen. In der Endphase verursacht die erhöhte Anschwellung des Endothels eine Verschlechterung der korpuskularen Durchströmung in den Kapillaren. Gleichzeitig entstehen zackig deformierte Erythrozyten. Stellenweise kamen an der Endothelwand befestigte Zellen mit kleinem Durchmesser vor, die nicht mit Sicherheit identifiziert werden konten. Eine Anlagerung von Granulozyten wurde nicht beobachtet. 
Die Anzahl der Thrombozyten verminderte sich und sie zeigten keine Adhesionstendenz. Granulare Veränderungen wurden in periendothelialen granulierten Zellen festgestellt. Reichliche diffuse perivaskulare Blutungen sind vorgekommen.

\section{SAMMANFATTNING}

Kapillärstruktur och kapillärfunktion hos hundar med experimentell Hepatitis contagiosa canis.

En vitalmikroskopisk studie.

Kapillärstruktur och kapillärfunktion har studerats på hundar med experimentellt framkallad Hepatitis contagiosa canis (H.c.c.). Observationerna har utförts $i$ ett intravitalmikroskop (Leitz) dels av konjunktivalkärl och mesenterialkärl dels av bindvävnad i öronkammare. Registreringen har skett på $16 \mathrm{~mm}$ färgfilm och med enbildsregistrering på svartvit film. Det kan konstateras ett karakteristiskt förlångsammat flöde $i$ venolerna med en hög arteriolo-venulär flödeskvot. I slutskedena orsakade en ökande endotelcellsvullnad försämring av det korpuskulära flödet i kapillärerna. Samtidigt uppträdde s. k. spikklubbeformer av erytrocyter. Ställvis förekom, till endotelväggen fixerade, icke säkert identifierade celler av liten diameter. Någon granulocytuttapetsering observerades icke. Trombocyterna voro reducerade till antalet och visade ingen adhesionstendens. Granulaförändringar kunde ses i periendoteliala granulerade celler. Rikligt med diffusa perivaskulära blödningar förekom.

(Received February 8. 1964). 